\title{
"Sisters in Arms": Slave Women's Resistance to Slavery in the United States
}

\section{Amrita Chakrabarti Myers}

\begin{abstract}
This paper examines the gendered nature of slave resistance in the nineteenth-century United States and illustrates the ways in which both gender and race shaped the institution of slavery. This examination is based on a collection of ex-slave oral interviews which were gathered in the 1930s in the Slave Narrative Collection of the Federal Writer's Project of the Works Progress Administration. Qualitative and quantitative analysis of the data reveal that slave women defended their own needs as slaves and challenged the system itself. The analysis broadens the traditional definition of "resistance," and illustrates the ways in which slave women carried out their day-to-day resistance to an oppressive system of servitude. Without women, slave resistance could not have been so throughly entwined into the fabric of everyday life as under slavery.
\end{abstract}

For many years historians have assumed that slave women did not play a significant role in slave resistance in the antebellum United States. This assumption is based in large part on the premise that since slave women were not involved in organized rebellions to the same extent as slave men, they were, uninvolved in efforts to resist slavery. It is mainly this narrow definition of the term "resistance" which has failed to take into account the gendered nature of slave resistance and has overlooked the many means by which slave women resisted their oppressors. Individual slave women resisted slavery on a daily basis in various, seemingly small, ways, which over time were more effective in weakening the power of owners because women were often successful in carrying out their resistance. In contrast, the collective plans of slave men were often uncovered before they could be carried out.'

A second factor in the exclusion of slave women from studies of resistance has been that many of the primary sources which mention slave women are oral narratives, 
sources which until relatively recently were widely shunned by historians as biased and unreliable. ${ }^{2}$ Ex-slave narratives, however, provide evidence of many incidences of resistance by slave women to slavery, as well as the nature of that resistance. These types of documents show that slave women resisted sexual assaults, feigned illness, were insolent, participated in work slow-downs and overt rebellions, murdered their masters, performed acts of sabotage, joined maroon colonies, and fled North to freedom. Black women resisted slavery with a passion equal to Black men. ${ }^{3}$ An examination of the Slave Narrative Collection of the Federal Writer's Project provides evidence of female slave resistance and adds to the existing historiographical debates surrounding such resistance.

A brief overview of slave resistance historiography will allow us to better understand the significance of the Slave Narrative Collection as a primary source. Slave resistance has long been a topic of great debate in the historiography of slavery. After World War I, historian U.B. Phillips put forward a paternalistic view of slavery which portrayed Blacks as a racially inferior, inherently passive people who were the contented slaves of moral, benevolent, paternalistic planters. On the basis of this assumption, Phillips stated that there were seldom Black revolts in the us because such behaviour would be incompatible with the inherently submissive nature of Black people, whom he characterized as inept, stupid, negligent, docile, inconstant, and dilatory. ${ }^{4}$

This picture of the slave South remained virtually unchallenged until 1943, when Herbert Aptheker published American Negro Slave Revolts. ${ }^{5}$ This book, which testifies to Aptheker's Marxist orientation, portrayed the American South as a dictatorial oligarchy where the lower class (the slaves) constantly rose up against the master class (the owners of production), in a manner similar to that of the Russian Revolution. A far cry from Phillips's paternalism, Aptheker's work documented hundreds of cases of slave resistance and concluded that slave revolts were not "aberrations," but constant elements of an ongoing process 
of resistance spread out over slavery's two-hundred-year history on the North American continent. Aptheker concluded that the social system was the primary factor in the existence of slave unrest. Slavery itself led to revolts, and discontent and rebelliousness were, therefore, characteristic of American slaves.

Stanley Elkins, in Slavery: A Problem in American Institutional and Intellectual Life, ${ }^{6}$ concurred with Aptheker's view that the slave South was a harsh and unkind place. Elkins, however, went on to state that slave plantations were similar to Nazi concentration camps, where the system was so harsh and dehumanizing that resistance was basically non-existent and futile. The legendary "Sambo" was not really a historical myth, but rather a product of the harsh and brutal system of American slavery which infantilized slaves and turned them into submissive, childish, dependent "Sambos." In light of this overwhelming oppression, Elkins concluded that the few slave revolts that occurred in the us were desperate and futile.

As slave-resistance historiography moved into the post-Civil Rights era, more studies appeared on slave resistance, many in response to Elkins. ${ }^{7}$ These new works stated that slaves had not been completely emasculated by slavery, nor were they psychically defenceless, but that they had exerted some autonomy over their own lives. Evidence of slave resistance proved that slaves were able to maintain some psychological, social, and cultural space, and these historians felt that in particular it was the aspect of slave culture which had allowed slaves to endure slavery. A number of these new works investigated this theory of slave resistance through aspects of slave culture including an area previously overlooked: resistance through slave religion.

One of these new monographs was Roll, Jordan, Roll, by Eugene Genovese, which stated that revolts, the ultimate manifestation of class warfare, were not a significant part of the process which eventually led to the overthrow of slavery. Genovese stated that slavery was 
a paternalistic system where slaves preserved their selfrespect through slave religion. He concluded that slavery did not create Sambos or guerillas, but that it created Blacks who could cope with the hardships of slavery through their religion, a religion which was a political weakness because it dictated the earthly acceptance of the hegemony of the oppressor, while waiting for the better days of eternal salvation. ${ }^{8}$

As historians have moved to respond to Genovese's theories, new ideas, issues, and glaring gaps have begun to emerge in the historiography of slave resistance. Perhaps the single largest shortcoming in resistance literature is the almost complete exclusion of any discussion of the participation of slave women. The few studies which have attempted to address this neglect are mainly in the form of articles by historians such as Betty Wood, Elizabeth Fox-Genovese, Darlene Clark Hine, Mary Ellen Obitko, and Mary Ellison. ${ }^{9}$ Other scholars, including Angela Davis, Jacqueline Jones, Deborah Gray White, and Leslie Schwalm, have included sections on slave women's resistance within their larger works on the lives of slave and free Black women. ${ }^{10}$

This growing secondary literature on slave women makes some basic assumptions about slave women and resistance. The first is that slave women were involved in a wide variety of resistance tactics, which included working slowly, falsifying illness, theft, and verbal retaliation; they were far from being docile "Mammies." Second, excluding the colonial period in American history, women were rarely involved in the planning and execution of large-scale, violent rebellions or insurrections. ${ }^{12}$ Third, due to the burdens of child care, pregnancy, and nursing, slave women were much less likely to run away than their male counterparts. ${ }^{13} \mathrm{Next}$, that slave women participated in forms of female-only resistance: inducing abortion, using birth control, faking pregnancy, and falsifying illness associated with pregnancy and menstruation. ${ }^{14}$ Ultimately, scholars argue that gender influenced the type of resistance in which a slave was 
involved. Men, physically stronger and not burdened by reproductive responsibilities, were more likely to participate in violent physical confrontations and be runaways. Slave women, better at forms of resistance not requiring physical strength, were dominant in theft and verbal retaliations.

Despite the agreements, there is also some debate within the literature on interpreting the role of slave women in resistance. One perspective insists that slave women attacked slavery as an institution. According to Darlene Clark Hine, "The slave woman's decision to resist was made consciously, with a full awareness of the political and economic ramifications involved."' Another viewpoint contends that a woman's prime reason for resistance was not political in its motivations or intent, but rather social, designed to maintain a state of "fairness" and dignity. ${ }^{16}$ The debate, then, is about the distinction between slave women's defense of their own needs within the status quo as opposed to a desire to change the status quo. In short, it is a question about slave women's consciousness.

In my research I analyzed a multi-volume set of primary source materials comprised of ex-slave narratives edited by George Rawick entitled The American Slave." These narratives are formally known as the Slave Narrative Collection of the Federal Writer's Project of the Works Progress Administration (WPA). An examination of these narratives demonstrates the extent of slave women's involvement in general day-to-day resistance, female-only resistance, violent resistance, and running away, and will hopefully add to the debates existent within the literature.

The WPA records, although a rich collection of antebellum slave narratives, are not without peculiar difficulties, many of which have been well documented..$^{18}$ For example, by the time the interviews were conducted almost seventy years had passed since the days of slavery, and this, combined with the advanced age of the informants, could have led to both memory loss and a distortion of the facts. ${ }^{19}$ Despite the limitations of the 
sources, however, we should by no means discard them, but rather be cautious both in our examination and in our conclusions. ${ }^{20}$ This collection contains a more diverse pool of informants than do published nineteenth-century ex-slave testimonies. It covers all the major slave occupations, spans the full range of landholding sizes, and details a complete range of slave treatment from paternal to sadistic. It tells us about antebellum southern life and slavery and, most importantly, it gives us the reactions and perspectives of the enslaved, allowing some of the lost voices from the past to be heard. The WPA collection, in fact, is the single largest, most in-depth body of evidence which exists on slavery from the perspective of the slave.

My research entailed an examination of all fortyone volumes of the ex-slave narratives, in which I read every citation listed in the index under the headings of "resistance" and "runaway slaves."21 Each citation was then categorised as to whether the subject mentioned was male, female, or gender unknown. The records of female resistance were then reclassified according to types of resistance. The female runaway records were then subdivided according to the reasons why the women ran away. Since many of the records contained more than one instance of resistance and/or running away, a straight tally between my numbers and the index would not be possible since it would appear as if I had more records than the index would indicate exist. In total I examined 631 records that contained evidence of resistance. Of these records, 445 ( 70 per cent) mentioned the gender of the person or persons involved. Of the 445 "gender-identified records," 209 (47 per cent) indicated incidents of resistance by a woman or women. I then subdivided the 209 female incidents into categories: "general resistance," "theft," "religious resistance," "conspiracy" or "networking," "female-only resistance," and "violent resistance." 
Many of the secondary sources refer to a wide variety of general or day-to-day forms of female slave resistance. Black slave women were involved in the destruction of farm tools and implements, were suspected of feigning illness to get out of work or receive lighter tasks, were routinely involved in verbal confrontations with owners and overseers, and were delibrately slow at their work, both in the fields and at the "big house."22 I identified 33 cases of "general resistance" by slave women in the WPA records. This resistance included work slow-downs, verbal retaliation, learning to read, and leaving the plantation without a pass. Of the five women who were reportedly not working fast enough in the fields, one, July Ann Halfen's mother, would stop doing her work so that she could nurse her children:

Mammy wud take her babies to de fiel' wid her an' put dem on a old piece uf quilt in de fence corners while she hoed or plowed, an' when de babies wud cry, she wud look 'round fur to see if de overseer wus in sight, so she cud stop an' nurse her babies. ${ }^{23}$

It seems plausible that Mrs. Halfen's post-partum condition, and her concern for the welfare of her children, may have contributed to her slower work. Another woman, singled out for not doing her share of work in the field, was to be whipped by the overseer. Angered, she picked up her hoe and chased him out of the field before he had a chance to beat her. ${ }^{24}$

By far the largest category under "general resistance" was what I have termed "impertinence" or "impudence." It would appear that slave women in the WPA records were quite willing to express their discontent through verbal confrontations and indirect retaliation. There were 19 such cases, ranging from the mild retaliation of one slave girl who dyed the new red shoes her master gave her because she hated red, ${ }^{25}$ to an illuminating story about a slave woman who was sent 
into town by her mistress to be beaten because she had fought off the sexual advances of the mistress's son. After she had been stripped naked and beaten in front of the town courthouse, she still had the energy to say of her tormentors: "They needn't think they had done somethin' by strippin' me in front of all them folk 'cause they had also stripped their mama's and their sisters. God had made us all, and he made us just alike." 26 It is clear that slave women were not afraid to denounce their masters, wear the kind of clothes they desired, curse those who laid hands upon their bodies, or attempt to shame Whites for unjust behaviour. Regardless of the conditions under slavery, it appears that slave women tried to retain a sense of dignity and faimess in all situations.

I found no m ention in the WPA records of what many historians consider to be the most pervasive form of female "passive" resistance, that of shamming illness. In addition to checking the citations under "resistance" and "runaways" in the index, I also examined almost 1,500 entries listed under "medical care," thinking this type of behaviour may have been categorised as "illness" as opposed to "resistance," but I still turned up no evidence. This does not necessarily mean that the feigning of illness did not exist, since the secondary sources contain many instances of this type of behaviour. ${ }^{27}$ This makes the silence in the WPA records all the more startling, leading me to conclude that perhaps this was one instance of possible ex-slave reticence during the interviews. If, as some historians have stated, the coercive atmosphere of the interviews (poor, Black ex-slaves interviewed primarily by middle-class Whites in the Jim Crow South), encouraged the recollection of only those cases of resistance that were justifiable, the lack of information on feigning illness-resistance without "just cause"-is perhaps more understandable. ${ }^{28}$

Another tactic classified under "general resistance" in the secondary literature was "theft" by slave women. I have classified it separately, since "theft" constituted 25 of my 209 female resistance records. The only classification 
to exceed this is one I will examine later: "violent resistance" by slave women. In Slavery Remembered, Paul Escott stated that slave women exceeded slave men in theft, and Betty Wood, in her article on female slave resistance in eighteenth-century Georgia, found that the majority of slave women incarcerated in the Savannah Gaol were there for theft..$^{29}$ Such action, therefore, requires separate examination, since it comprised such a significant portion of slave women's resistance.

Were the thefts described in the WPA records a form of resistance with a deliberate political consciousness? Did they constitute a political desire to take away from those who had so much, or was it theft of a more social nature, stealing to survive, to assuage hunger, or even as mere pranks? Of the 25 records under "theft," 12 indicate that the items taken were food, stolen because the slave was hungry. Ex-slave Jenny Proctor remembered eating a biscuit she found while she was cleaning the house. When her mistress accused her of taking it, she admitted it, saying she was hungry. Her mistress beat her for this and Jenny fought back, incensed at the injustice of the situation. ${ }^{30}$ Another slave woman stole and slaughtered her master's hogs to feed her family the meat which they desperately needed but were not given. ${ }^{31}$ The other 13 thefts in the records identified slave women who stole food, not neccessarily out of hunger, but because they wanted something they were not usually given. One woman said that they were given lots of pork but never chicken, so this is what she would steal, while others stole luxury items such as peaches, cookies, and flapjacks. Henry Cheatam's mother used to send her son out to steal for her and he "hid many a night in de fence corners when I'd be a goin' som'ers to git my mammy some 'bacco." 32

Overall, it seems that slave women mostly stole food, and that they stole it either to meet basic human needs or to satisfy cravings and desires. Although there was no mention of thefts being made with any sort of a political conscience to deprive the master or to get 
back at the system, we must remember the limitations of the sources we are working with and what may have remained unsaid. It may be reasonable to assume that ex-slaves living in the South during the Great Depression, an era of severe food shortage, would not mention stealing food for the pleasure of getting back at their owners, but rather that they stole due to hunger, a reason with which their White interviewers could have understood and empathized, given the economic situation at the time.

An area of resistance that went unmentioned in most of the secondary literature was the involvement of slave women in religious resistance. Elizabeth Fox-Genovese touched on this when she stated that slave churches played a large role in organizing revolts and resistance tactics. Women were active in these churches and in slave religion overall, so why was it that their participation often went unmentioned in this forum of resistance? Fox-Genovese believed it was because the collective efforts of slave men were discovered and then punished, whereas the more individual efforts of women remained undetected and were successful. Therefore, it was slave women who kept the resistance tradition alive and growing in community churches and within their families after the men had been discovered and then killed or sold away. Religion was the foundation of resistance, and slave women played a crucial role through a religious sisterhood..$^{33}$

My research uncovered 23 instances of women who resisted by praying and being "externally" religious when it was forbidden by their masters, or who specifically used their prayers to ask for freedom. Adeline Cunningham remembered, "No suh, we never goes to church. Times we sneaks in de woods and prays de Lawd to make us free ... dey heered at de big house and den de overseer come and whip us "cause we prayed de Lawd to set us free." ${ }^{34}$

Many slave women participated in religious resistance simply by praying. They would praise the 
Lord in the fields, pray in their homes with the "pots turned down" to catch the echoes, sneak off to the ditches to pray, or go into the woods to participate in secret collective prayer meetings where the topic was freedom. ${ }^{35}$ Slave women prayed alone or in groups with their children and slave men, and always in secret, for they knew the consequences of discovery. Regardless of the cost if caught, slave women continually prayed for freedom, for salvation, and for retribution, and used their religion as an underground forum for resistance of a decidedly political nature.

Much of the secondary literature mentioned strategies of resistance that were designed to spread information and obtain for the slaves the best conditions that they could from their masters. These included things like holding secret group meetings, eavesdropping and carrying secret information to other slaves, and playing different groups of Whites off against one another. Slaves especially utilized class differences to their advantage, setting owners against overseers. ${ }^{36}$ Historian Jacqueline Jones has also discussed other covert tactics used by women, such as feeding runaway slaves on the sly. She stated that this was a subversive tactic that held great political significance for social relations on the plantation. ${ }^{37}$ I have grouped these types of behaviours under the heading of "conspiracy or networking" tactics.

The WPA records provide some interesting information on these undercover types of resistance. A total of 21 incidents reveal that slave women participated in undercover work to carry information to other people. Ex-slave Bert Russell stated that the slaves on the plantations were eager for outside news. It was difficult to get, because plantation owners were extremely cautious about their slaves getting any outside information; however,

the greater the precaution the alerter became the slaves, the wider they opened their ears and the more eager they 
became for outside information. The sources were: Girls that waited on the tables, the ladies' maids and the drivers; they would pick up everything they heard and pass it on to the other slaves. ${ }^{38}$

Young girls also ferried information about the Civil War to the barracks of the slaves. Former slave Elizabeth Russell mentioned that although she was very small during the war, she served her people as a "secret service agent." She worked in the big house minding the babies and would often pretend she was asleep while listening to what was being said about the war and who was winning. She stated that, "When the word came that the North had won and the slaves were free, it was I who carried the word to the hundreds of slaves in our section." $" 39$

Women were also adept at playing overseers and masters, and mistresses and masters, against each other. In some such instances they wished to improve their position on the plantation. For example, some slave women managed to get the overseers on their plantations fired by reporting to the master that the overseer was stealing food or inflicting unnecessary punishment. ${ }^{40}$ In other instances, though, slave women would use this tactic as a form of revenge against one of the parties involved.

Master Jim's wife was a demon ... every time Master Jim come home he whip me cause the mistress say I been mean ... while Master Jim is out fighting the Yanks, the mistress is out fiddling round with a neighbour man, Mister Headsmith ... The mistress didn't know I knows her secret, and I'm fixing to even up the score for some of them whippings she put off on me. That's why I tell Master Jim next time he comes home. ${ }^{41}$

Esther Easter's revelation netted her mistress a beating from her husband that almost killed her. This is a tragic, yet not unusual occurrence, involving Black and White female relations in the slave South. Women, at times 
unable to lash out directly at one another, instead "spoke" to one another through the violent behaviour of White men. Slave women knew that to avenge themselves directly against White women would only result in more punishment, while White women knew that their men could punish slave women far more effectively than they themselves could. Each side, then, at times depended on the violence of White men to vent their frustrations towards the other.

Personal motivations aside, there were also 10 records which mentioned women involved in the very political act of feeding runaway slaves. Candus Richardson's master struck her and left a hole in her head because, "he caught me giving a runaway slave something to eat at the back door of the big house." Other slave women aided runaways by hiding them in their homes in closets or helping them go North, while ex-slaves like Martha Jackson gave aid to runaways through silence. Although Martha knew where a male runaway slave was hiding, when her mistress asked her if she knew where "Don" was at she, "never said nothin' ... and he peered up atter de s'render." ${ }^{\prime 2}$ Although revenge and a strong desire for fair working conditions did motivate some of their actions, it is also evident that slave women had a political consciousness and used it to further the cause of freedom for their people, even if it meant helping just one fugitive slave.

Perhaps one of the most divisive areas for scholars is the ongoing issue over "female-only" resistance, which included faking pregnancy, shamming illness related to pregnancy or menstruation, abstaining from sexual intercourse, refusing to marry, using birth control, inducing abortion, committing infanticide, and defending oneself against rape. For instance, many historians claim that slave women faked pregnancy because pregnant women were given lighter tasks and could expect larger food rations. It was a type of resistance in a class by itself, since it was almost inevitable that the fraud would be discovered 
sooner or later. Plantation mistress Frances Kemble mentioned in her diary,

the pseudo-pregnancy of a woman called Markie, who for many more months than are generally required for the process of continuing the human species, pretended to be "in good hope" and continued to reap increased rations as the reward of her expectation, till she finally had to disappoint the estate and receive a flogging. ${ }^{43}$

The secondary literature also contains examples of many slave women who professed unusual illness or weakness during pregnancy and menstruation in order to avoid certain types of work or eliminate work altogether. Deborah White mentioned two women, a slave named Criss who was bedridden for the majority of her pregnancy due to unusual weakness, and a slave woman named Maria on President James Polk's plantation who was besieged by horrible fits every three or four weeks during menstruation until she was given an indoor job weaving cloth. ${ }^{44}$

It would seem that female slaves could and did claim unusual discomfort and weakness during pregnancy, although it is difficult to prove whether these problems were real or not, or whether these tactics successfully alleviated or eliminated their workload. What it did reflect was not only a desire to work less, wrote Elizabeth FoxGenovese, but it was also a direct challenge to the master saying, "You want me to reproduce as a woman, treat me as a woman."45 While slave owners had a vested interest in keeping slave women healthy and reproducing, the relatively better care women and expectant mothers received was as much a result of the pressure slave women exerted as of self-serving benevolence extended by slave owners and overseers. ${ }^{46}$

Some historians also argue that slave women refused to reproduce for a variety of reasons, including the desire not to bring children up as slaves, the fear of the dangers of childbirth, and rebellion against the pressures to reproduce for profit. ${ }^{47}$ White stated in her work that some southern Whites were certain that slave women 
knew how to avoid and abort pregnancy. Among others, she quoted a southern physician, Dr. John H. Morgan, who was positive that slave women knew of, and used, herbal abortifacients. He stated that, "Often they will attempt to bring all the aids into requisition that they can ascertain that will increase the parturient effort, either by medicine, violent exercise, or by external and internal manipulations." ${ }^{18}$ Another physician, Dr. E.M. Pendleton, believed that slaves were, "possessed of a secret by which they destroy the fetus at an early stage of gestation." 49 Pendleton's belief, White maintained, was not without foundation. There were, for example, entire families of Black women who did not have any children. She also mentioned the case of the slave woman who was sold in 1857 because she was barren, but who had three children after the Civil War. ${ }^{50}$ Darlene Clark Hine also suggested that many slave women resisted breeding through abstinence as well as abortion in order to deny their masters economic gain through their bodies, and to ensure that no more Blacks would grow up in bondage. Hine concluded that if all slave women had felt this way, slavery would have died out. ${ }^{\text {sI }}$

Some scholars, however, inluding Eugene Genovese, felt that abortions and infanticide were not a real problem for the master class, nor an ordinary tactic on the part of slave parents, because they loved their children too much to harm them. Genovese maintained that this type of behaviour only occurred under special circumstances, pointing to the paucity of recorded instances. ${ }^{52}$ Elizabeth Fox-Genovese supported this viewpoint. She believed that such behaviours were rare, and that it would be difficult to prove the effectiveness and importance of these tactics within a growing slave population. She also stated that not many slave women would have opted for infanticide as a form of resistance because they loved their children too much. Last, Fox-Genovese pointed out that we have no way of knowing whether slave women practiced abortion and infanticide selectively, for example, terminating pregnancies or killing children which were the result of 
rapes by White men. Such actions, she stated, would be a real indication of resistance. ${ }^{53}$ Darlene Hine took this viewpoint to task, stating that just because the behaviour was infrequent did not make the cases which existed any less significant. The fact that abortion and infanticide occurred at all was what was important, and she pointed out that there were cases where women preferred to kill their children as opposed to letting them grow up under slavery. Death became a higher form of love, and a clearer indication of the living death that slavery was. ${ }^{54}$

What, then, do the WPA records add to this debate? As there were no index headings in the WPA records for any of these types of "female-only resistance," I again, in conjunction with the resistance records, examined the citations listed under "Medical Care." First, there are no records of slave women faking pregnancies, feigning pregnancy-related illness, or having abortions. There were, however, 4 records that clearly indicated the use of birth control. A slave woman named Mary chewed cotton roots to prevent conception after her master made her marry a man she hated. After freedom came, Mary had five children with a new husband of her own choice. Another woman said that slave women induced miscarriages by taking calomel, turpentine, and indigo. Former slave Anna Lee claimed that female slaves had started chewing cotton roots to keep from having any more babies, and that if slavery had lasted much longer, there would have been only old people left because "we had done quit breeding."

Although the WPA collection contains no evidence of false pregnancies, false illness relating to pregnancies, or abortions, and a very small number of cases of birth control, this does not necessarily mean that these behaviours did not exist, or that these were merely the actions of a few women. Instead, we should consider whether any of these topics, especially abortion or birth control, would have been mentioned by the ex-slaves. First, these are extremely private subjects, not easily discussed with White strangers. Second, these were 
issues which were being hotly debated in the 1930 s, and many people felt that it was immoral to participate in such behaviours, especially abortion. Ex-slaves may have feared censure if it was discovered that they knew how to prevent or terminate a pregnancy. Finally, there is the possibility that these recollections may have been deleted from the transcripts by the interviewers because they were embarrassing or potentially explosive.

Despite the silence of the records in certain areas, I did find mention of 2 instances of infanticide, 12 cases of resisting rape, and 4 cases of women who resisted marriage. One of the instances of infanticide occurred when a slave family on the run was captured. Determined that her daughter would never again live as a slave, this slave mother killed her child rather than let it be returned to slavery. ${ }^{56}$ The other case of infanticide is particularly poignant. It involved a slave mother who was a "good breeding woman" and had produced many children. Every time that an infant would be weaned off her breastmilk, the master would sell it. She lost four or five children this way and became very agitated about losing her latest child. She continually talked about this in front of a large group of slaves and finally said that the Master was not going to sell this baby away from her and have who knows what happen to it. She gave the infant something from a bottle she had nearby, and within a few minutes the child died. ${ }^{57}$ It seems that some mothers were willing to kill for what Darlene Hine termed a "higher form of love."

Resisting rape was also an area of resistance which primarily involved slave women. Paul Escott stated that slave men generally protected their women from sexual attacks, but that slave women were not hesitant about defending their virtue when necessary. ${ }^{58}$ Based on my research in the WPA records, I would agree that slave women were not loath to protect themselves, but would also contend that slave men did not usually protect their women because they could not do so without bringing 
violence upon themselves. Slave women, by and large, had to fend for themselves and did so admirably. For example, ex-slave Gus Feaster's mother and a woman named Lucy were out picking blackberries with their sons when an overseer rode up and demanded that the two women have sex with him. They tried to verbally refuse him at first, saying they were religious women and did not sin.

Finally he got down off $n$ his hoss and pull out his whip and low if dey didn't submit to him he gwine to beat dem half to death ... finally dey act like dey gwine to indulge in de wickedness ... But when he took off his whip and some other garments, my Mammy and ole lady Lucy grab him by his goatee and further down and hist him over in de middle of dem blackberry bushes. ${ }^{39}$

The two women then proceeded to run to the big house and told the mistress what had happened. She promptly sent for "Mr. Evans" and fired him.

Although some women were obviously successful in their resistance, there were many cases where resistance was overcome by the master class. Of the 4 cases of resisting marriage mentioned previously, only one of the women successfully avoided the marriage, ex-slave James Martin's mother. She wanted to marry a free Black man, but her mistress refused to give her permission, telling her she had to marry a slave because otherwise her children would be free, which would result in a loss of property to the mistress. The master told James's mother that if she could raise $\$ 1,200$ she could buy her freedom. It took her and Preston Martin a long time, but they finally managed to raise the money and got married. Here was one woman who refused to be wed and bred for her owner's economic gain. ${ }^{60}$

The last subset of resistance to be examined is also one in which there exists a fair amount of controversy in the historiography: "violent resistance."Within the general secondary literature, the primary focus has been on slave women's role in organized revolts and rebellions. Angela Davis contended that 
Black women played significant roles in slave rebellions, listing at least nine different uprisings where women were caught and punished as collaborators." ${ }^{161}$ The extent to which women participated in larger rebellions, however, seems to be an area of contention. Other historians, including Mary Ellen Obitko, argued that women were not involved in leadership positions in rebellions, rather that they were strictly participants. ${ }^{62}$

In addition to organized violence, the secondary literature states that slave women were also involved in murder, arson, violent refusal of punishment, poisoning, self-mutilation to thwart sales, and suicide. For example, there was a slave woman named Crecie who whipped an overseer who had dared to whip her, while another slave woman was burned at the stake in 1755 in Charleston for poisoning her master. Betty Wood noted that there were slave women in the Savannah Gaol for murder, attempted murder, arson, and assault. Although the number of women incarcerated for these types of crimes was low, Wood contended that their existence was what was important, providing evidence that overt resistance was not solely the arena of men. ${ }^{63}$ Fox-Genovese took a step beyond this to analyze what she saw as the different roles played by men and women in violent resistance. She stated that the existence of gender differentiation, exemplified by weaker female physical strength and reproductive burdens, shaped slave women's resistance, making it much more individual than collective. In short, Fox-Genovese felt that gender-specific labour assignments, reproductive responsibilities, and physical weakness kept women from participating in violent, organized, collective resistance, and from running away. ${ }^{64}$

"Violent resistance" by slave women is the largest category of female resistance in the WPA records with 56 entries. Although there is no mention of women's involvement in collective resistance, the records include 1 entry of "arson," 4 of "suicide," and 31 of women 
who refused to be beaten and retaliated violently. For example, Dinah Watson's Aunt Susie Ann did something to offend the overseer, and he,

beat her till the blood run off her on the ground. She fall at his feets like she passed out and he put up the whip and she trips him and gits the whip and whips him till he couldn't stand up. Then some niggers throwed him off a cliff and broke his neck..$^{\text {s3 }}$

Women also used violence to take revenge for a previous insult or injury done to them or to a loved one. Mary Armstrong did exactly that when she attacked her old Mistress, Miss Polly:

One day old Polly devil comes to where Miss Olivia lives after she marries, and tries to give me a lick out in the yard, and I picks up a rock "bout as big as half your fist and hits her right in the eye and busted the eyeball, and tells her that's for whippin' my baby sister to death. ${ }^{66}$

Murder was also not beyond slave women as a form of revenge. One Black woman who was beaten "near "bout to death" by the overseer got so mad that she took up his child and "th' owed it in a pot of lye dat she was usin' to wash wid." The mother came running out screaming and tried to rescue the child, "but it didn't do no good 'caze when she jerked de chile out he was daid." ${ }^{67}$ Another slave woman, named Sallie, lived on a plantation where the master would beat his slaves when they came home from the fields, lock them up for the night, and then beat them before he let them out in the moming.

So mah cousin Sallie watched him hide de key an she moved dem a li'l further back so dat he had tuh lean ovah tuh reach em. Dat mawnin soon when he come tuh let em out she cracked him in de haid wid de door an made little Joe help put his haid in de fiuh place. Dat day in de fiel' little Joe made er song: 'If you don' bleave Aunt Sallie kilt Marse Jim de blood is on huh under dress.' He jes hollered hit. 
'Aunt Sallie kilt Marse Jim.' Dey zamined Aunt Sallie's under dress so dey put huh in jail till de baby come den dey tried huh tuh be hung an she wuz. ${ }^{68}$

Violence was also an instrument slave women used to resist sale. Sometimes the violence was directed towards themselves, sometimes others, but they did not hesitate when they felt that they had been wronged. One woman, who had been beaten until her back was broken by her mistress for failing to finish the churning on time, was auctioned off because she was no longer of any use. "One man bid $\$ 1700.00$ after puttin" two dirty fingahs in my mouth to see my teeth. Ah bit him and his face showed angah. He wanted to own me so he could punish me." 69 Nancy Rogers Bean's aunt was more drastic in her measures. She was a "mean, fighting woman" who was to be sold because of her bad nature. "When the bidding started she grabbed a hatchet, laid her hand on a log and chopped it off. Then she threw the bleeding hand right in her master's face." Another case indicating how much slaves hated being sold away from family was that of Cleve and Lissa Lawson. Lissa Lawson was to be sold away from her husband and children because their master knew he could make a large profit on the light skinned woman. The husband and wife jumped their master and tied him up, telling him that if he agreed to back out of the sale, they would let him go.

But Marse Drew shook his head an' cussed in his th'oat. Den dey took off de gag ... stuffed de spout of a funnel in his big mouf way down his th'oat ... They ax him one more time to save Lissa from the block, but Marse Drew ... shook his head again ... Lissa bring a pitcher of boilin' water ... an' hol' Marse Drew's head so he couldn' move ... an' dey poor dat water down his th'oat till he died ... refusin' to change his mind no matta how many time they ax him.7"

Slave women also used suicide as a method of resistance against oppressive masters and unbearable circumstances. Ex-slave Annie Tate's grandmother 
killed herself because they had sold her husband away from her. Mrs. Tate said that her mother was only ten years old when all this happened, orphaning her mother in the space of about one week. ${ }^{22}$ Slave women, it seems, were assertive women who were not afraid to stand up for themselves, and who were not above resorting to violent resistance to right a past wrong or prevent a wrong from occurring. Far from being physiologically handicapped, these were women who took part in violent resistance without ever considering that they were the "weaker sex." Perhaps this was because when it came to their labour on the plantation, slave women were expected to work as long and as hard as male slaves, the ideology of "separate spheres" quickly forgotten by Whites in the face of economic gain. Slave women, having neither the luxury nor the burden that accompanied being put on a pedestal, actively participated in violent resistance.

The final area to be examined is that of female "runaways." Using the methodology outlined earlier, I searched through all of the citations listed under "Runaways" in the WPA index and tabulated a total of 884 people who ran away. Unlike the resistance records, where I counted incidents, for the runaway records I counted the number of people who ran away, not the number of times they ran away. Of the 884 cases, 559 (63 per cent) mentioned the gender of the person or people running away. Of these 559 cases, 143 (26 percent) were women. Where does this information fit in the historical record, and what new insights, if any, does it add?

Most of the secondary literature agrees that for various reasons slave women were less likely to run away than slave men. They were not trained in any artisan skills that would have given them a valid reason to leave the plantation for the purpose of work. They were not hired out to other plantations, being kept on their own plantation as field hands and house servants. Female house servants found their 
opportunities further limited since they were continuously under the watchful eyes of the mistress. Deborah White further stated that slave women were hampered from running away because of their reproductive and childcare functions and responsibilities. Running away was almost impossible for the woman who chose to take her children with her, for she increased her risk of capture. It was equally difficult to leave them behind, not knowing what could happen to them after she left. In fact, Betty Wood claimed that no slave woman would run away and leave her children behind. Last, most women between the ages of 17 and 35 were unable to run away since they were either pregnant or nursing during these "prime" runaway years. They probably received their best treatment as slaves during this period, White argued, giving them another reason not to leave. ${ }^{73}$

Coupled with their maternal desires to be near their children, these restrictions supposedly led more slave women to choose short term absences, or truancy, instead of permanent escape. For example, a women could run away to the woods or a nearby cave to escape a beating, returning after the master or overseer had cooled off. Meanwhile, they were close by, able to slip back at night to visit their families and get food. Truancy could also give slave women a tool with which to bargain over their treatment. A slave woman could send messages to the master saying that she would return if he did not hurt her, or if he gave her something she wanted, like a trip to visit a family member on another plantation. Much of the secondary literature states that masters, not wishing to lose a woman's economic and reproductive labour, would usually comply. ${ }^{74}$

The WPA records provide an interesting glimpse into how slave women ran away, why they ran, and with whom. I divided the 143 records that involved women into two sections, "runaways" and "truants." With longterm runaways comprising 105 of the 143 cases, one notes a stark contradiction to the claims that truancy was the more viable option to slave women. Perhaps the 
most interesting finding in the runaway records is that one of the most common reasons given for running away was one which went unmentioned in the secondary literature: the desire to be reunited with family. There were 19 women who ran away to find their families again, 8 of whom tried to reunite with their husbands. Dorcas was sold away from her husband and children, so she ran away from her new owners and spent months making her way back to her family in South Carolina:

She stayed in the woods at night ... she would kill rabbits and squirrels and cook and eat in the woods ... and beat anyone that tried to stop her from coming back ... she did get back ... and Col. Elmore was glad ... he told her he was not going to let anybody take her off. ${ }^{75}$

Family, it seems, was important enough for women to risk their lives. Slave women braved recapture, beatings, sale, and imprisonment to return to their homes, their children, and their spouses, regardless of how difficult the journey.

Many slave women ran away because of punishment. There are 28 instances of women who ran away to escape excessive beatings, to keep from being raped, or who left after a rape had occurred. One woman was whipped so severely that she ran away to escape further abuse. Her master's dogs tracked her to a tree where she stayed for two days. She finally came down after she had negotiated a deal whereby she would be whipped no more. Her master kept his word. ${ }^{76}$ Another slave woman, Harriet Clemens, left her home to escape being raped. Her daughter remembered that,

It was on 'count o' de Nigger overseers ... Dey kep' atryin' to mess 'roun' wid her an' she wouldn' have nothin' to do wid 'em. One time while she was in de fiel' de overseer asked her to go over to de woods wid him an' she said, 'All right, I'll go find a nice place an' wait.' She jus' kep' a-goin." 
One woman who was raped by her master ran away and was missed when she did not come to the big house to nurse the child who was the product of the rape. The dogs were set after her and, although she tried to climb a tree, the dogs pullled her down and ate the breasts off her body. "She got well and lived to be a old woman, but 'nother woman has to suck her baby, and she ain't got no sign of breasts no more." 78

Thirty-three women also escaped because they desired freedom from slavery itself. Ex-slave Charles Willen had a sister who made it North to freedom, although he never attempted escape himself. Still another woman fled North with her husband, leaving her child behind on the plantation. ${ }^{79}$ Women, it seems, were willing to run away and were more likely to become fugitives than truants, according to the WPA records. They ran away to escape punishment, to find family, or to be free, and they almost always ran away without men. This is interesting since, according to White, women who ran away without a man were three times more likely to be caught. ${ }^{80}$ Only 14 of the 105 WPA women who ran away were ever caught and returned to their masters.

The most startling finding in the records is that of the 34 women who were reported to have children, only 15 of them took their children with them, shattering the assumption that slave women would not run away because of, and without, their children. Nineteen slave women left their children behind, despite the heartache it surely caused. Harriet Clemens, the slave woman who ran away from the advances of the Black overseer, left behind several children including the daughter who recounted her story, starting the tale with the statement, "My mammy's name was Harriet Clemens. When I was too little to know 'bout it she run off an lef' us." ${ }^{81} \mathrm{Far}$ from being uncaring mothers however, 9 of the 19 mothers who left their children behind returned to 
find their children after the war, including Harriet Clemens. Callie Washington's mother also returned for her daughter after the war had ended:

My Mammy and Daddy ran off. I didn't see them no more till after peace was declared. She came after me and brought two colored Yankee soldiers with her ... She said she come to get me, and she was going to carry me back. ${ }^{\text {2 }}$

Of the 10 women who left their children behind, 5 never returned and 3 were captured and returned to their plantations. Two others returned to find that their children had been sold away and were never able to locate them. ${ }^{83}$

Of the 38 truancy incidences, 17 women were truant for undisclosed reasons, while another 9 said that they just wanted to get away for a while. Another 12 went truant to escape punishment or sale. One such woman was Easter Wells's mother. She was the cook on their plantation, and one day she burnt the bread.

She knowed dat old Master would be mad and she'd be punished so she got some grub and her bonnet and she lit out. She hid in de woods and cane brakes for two weeks and dey couldn't find her either. One of de women slipped food out to her. Finally she came home and old Master give her a whipping but he didn't hurt her none. He was glad to get her back. ${ }^{84}$

Emmanuel Elmore's mother got drunk and got into a brawl with the men in the slave quarters. Fearing that she would be sold, she ran off to the woods for a month. Her husband took food out to her, and she only returned after their master told her husband to bring her back as "he was tired of having his rations carried to the woods."

Based on my research, the WPA records on female slave runaways agree and disagree with existing scholarship on slave women. Although the overall number of slave women who ran away was smaller than that of men, they were more likely to run away than to 
be truant, they ran away without male escorts, and they were willing to leave their children behind. They were also very likely to return and reclaim their children when the time was right. Slave women had a deep commitment to family, and they exemplified this by running to their families, leaving them only under great duress, and returning to them as soon as possible.

Many social scientists have discovered that the oral testimonies of everyday people are equivalent to the diaries, letters, and written memoirs of privileged people, neither one being particularly unbiased or objective ${ }^{86}$ If we are to know the details of the slave heart, we must study Black testimonies as we study White ones, accepting that neither side had a monopoly on the truth. Some questions can only be answered by the slaves themselves, such as questions about mentality, life experiences, needs, and their perspective on bondage. As these and other new questions are raised, especially those which have to do with slave women, the slave psyche and the experiental world, the Slave Narrative Collection will assume new significance. If slavery is to be seen from the point of view of the enslaved, these records are an essential source of data.

This research suggests the following conclusions. First, Black women were far from being "mammies" who collaborated with the master class, and instead promoted and practiced resistance to slavery. Historians who have assumed that slave women did not resist because of minimal evidence of their involvement in organized rebellions are mistaken and need to re-examine their definition of "resistance." Second, slave women daily encouraged their people to look for freedom and refused to passively submit to bondage. They were as willing to resort to violence as slave men, the difference being that their actions tended to be individual rather than collective. This did, in fact, give them an edge because while the actions of slave men tended to be discovered before any collective 
action could occur, the actions of individual women were harder to predict and, therefore,more often met with success. Third, despite the burdens of pregnancy, childbirth and childcare, slave women ran away and participated in types of violent resistance from which some historians felt they were excluded due to their physiological make-up. Fourth, although slave women participated in certain types of "female resistance" that men did not, gender did not keep women from participating in the types of resistance in which slave men were involved. Finally, I would suggest that many of their actions were politically motivated, like feeding runaways, practicing birth control and infanticide, and praying for freedom, while others appear to have been more socially motivated, such as stealing to combat hunger or avenging a past wrong. One thing is clear though, and that is that slave women wove resistance into the fabric of daily life under slavery. Slaves were not a docile people, and they made it a general policy not to let the master win. ${ }^{87}$ This spirit was evident in the slave woman who, despite her burdens, retained a measure of strength, independence and a spirit which demanded certain basic rights. Slave women did resist and were a threat to the southern system of slavery. Implicit in their resistance was a refusal to accept their dictated roles as labourers and reproducers for the economic gain of their masters, attacking the very assumptions upon which the slave order was based. ${ }^{88}$

'Mary Ellen Obitko, “'Custodians of a House of Resistance': Black Women Respond to Slavery," in Black Women in United States History, v. 3, ed. Darlene Clark Hine(New York: Carlson Publishing, 1990), 994. Originally published in Women and Men: The Consequences of Power, ed. Dana V. Hiller and Robin Ann Sheets (Cincinnati: University of Cincinnati Press, 1977), 256-269.

${ }^{2}$ Elizabeth Fox-Genovese, "Strategies and Forms of Resistance: Focus on Slave Women in the United States," in Black Women in Uniled States History, 413 . Originally published in In Resistance: Studies in African, Afro-Caribbean and Afro-American History, ed. Gary 
Okihito (Amherst: University of Massachusetts Press, 1986), 143165.

${ }^{3}$ Angela Davis, Women, Race and Class (New York: Vintage House, 1983), 23.

${ }^{4}$ Ulrich B. Phillips, American Negro Slavery (New York: Appleton, 1918); Ulrich B. Phillips, Life and Labour in the Old South (Boston: Little and Brown, 1939); see also Review by John B. Boles of Phillips: A Southern Mind by John Herbert Roper, North Carolina Historical Review, 62(January 1985): 105.

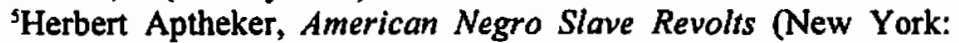
Intemational Publishers, 1943); see also Review by W.M. Brewer of American Negro Slave Revolts by Herbert Aptheker, Journal of Negro History 29 (1944): 88.

'Stanley Elkins, Slavery: A Problem in American Institutional and Intellectual Life (Chicago: University of Chicago Press, 1968).

${ }^{7}$ Lawrence Levine, Black Culture and Black Consciousness: AfroAmerican Folk Thought From Slavery to Freedom (New York: Oxford University Press, 1977); Albert Raboteau, Slave Religion: The "Invisible Institution" in the Antebellum South (New York: Oxford University Press, 1978); and Peter Wood, Black Majority: Negroes in Colonial South Carolina From 1670 Through the Stono Rebellion (New York: W. W. Norton, 1975).

${ }^{8}$ Eugene Genovese, Roll, Jordan, Roll: The World the Sloves Made (New York: Random House, 1976), 125, 146-147, 254.

'Betty Wood, "Some Aspects of Female Resistance to Chattel Slavery in Low Country Georgia, 1763-1815," The Historical Journal 30 (3) (1987): 603-622; Fox-Genovese, "Strategies and Forms of Resistance," 409-431; Darlene Clark Hine, "Female Slave Resistance: The Economics of Sex," in Black Women in United States History, v. 2, ed. Darlene Clark Hine (New York: Carlson Publishing, 1990), 657666. Originally published in The Western Journal of Black Studies 3 (Summer 1979): 123-127; Obitko, "Custodians of a House of Resistance," 985-998; and Mary Ellison, "Resistance to Oppression: Black Women's Response to Slavery in the United States," Slavery and Abolition (Great Britain) 4 (1)(1983): 56-63.

'Davis, Women, Race and Class, 23; Jacqueline Jones, Labor of Love, Labor of Sorrow: Black Women, Work, and the Family From Slavery to the Present (New York: Basic Books, 1985); Deborah Gray White, Ar'n't I a Woman?: Female Slaves in the Plantation South (New York: W.W. Norton, 1985); Leslie Schwalm, "The Meaning of Freedom: African-American Women and theirTransition from Slavery to Freedom in Lowcountry South Carolina" (PhD diss. University of Wisconsin-Madison, 1991).

"Obitko, "Custodians," 987-988.

${ }^{12}$ Fox-Genovese, "Strategies and Forms of Resistance," 410-11, 41 5; Betty Wood, "Some Aspects of Female Resistance," 611; Angela 
Davis, "Reflections on the Black Woman's Role in the Community of Slaves," The Black Scholar (December, 1971): 10-1 1.

${ }^{13}$ White, Ar'n'l I a Woman?, 70, 76; Paul D. Escott, Slavery Remembered: A Record of Twentieth-Century Slave Narratives (Chapel Hill: The University of North Carolina Press, 1979), 90; FoxGenovese, "Strategies and Forms of Resistance," 416.

${ }^{14}$ Escott, Slavery Remembered, 87-90; Fox-Genovese, "Strategies and Resistance,"422-423.

${ }^{15}$ Hine, Female Slave Resistance, 664.

${ }^{16}$ Escott, Slavery Remembered, 87-90; White, Ar'n'll a Woman?, 76. ${ }^{17}$ George P. Rawick, ed. The American Slave: A Composite Autobiography (Westport, CN: Greenwood Press, 1972 and 1977). All primary sources within this paper have been taken from this collection except where indicated otherwise, and will be cited with series, volume, and page numbers for complete reference. See note 21.

${ }^{18}$ Many historians have stated that these narratives are problematic for a variety of reasons including the following: the fact that those interviewed were not a random sample; that all states were not equally represented in the interviews; the old age of the exslaves during the interviews which could perhaps lead to faulty memory; the passage of time since slavery which could have led to forgetfulness; the fact that these ex-slaves had been young children during slavery and had not really been exposed to the harsh realities of life as a slave; the lack of methodology on the part of the interviewers questions; the fact that the middle-class, White interviewers were racist, untrained, and could have prevented the true recollection of memories amongst the exslaves in the Jim Crow South; and the possibility that we have no way of knowing if what we read are the true words of those interviewed because the interviewer has inserted him or herself between ourselves and the ex-slaves. For a detailed examination of these problems, please see the following: John Blassingame, "Using the Testimony of Ex-Slaves: Approaches and Problems," in Revisiting Blassingame's The Slave Community: The Scholars Respond, ed. Al-Tony Gilmore, (Westport, CN: Greenwood Press, 1978), 169-188; Escott, Slavery Remembered, 6-17; review by Virginia V. Hamilton of Up Before Daylight: Life Histories from the Alabama Writers' Project, 1938-39, ed. James Seay Brown, Jr., in Alabama Review 36 (July 1983): 220-221; Donald M. Jacobs, "Twentieth-Century Slave Narratives as Source Materials: Slave Labor as Agricultural Labor," Agricultural History 57 (2) (1983): 223-227; P.M. Mercer, "Tapping the Slave Narrative Collection for the Responses of Black South Carolinans to Emancipation and Reconstruction," Australian Journal of Politics and History 25 (3) (1979): 358-374; George P. Rawick, From Sundown ro Sunup: 
The Making of the Slave Community, v. 1 of The American Slave, xvii-xviii; C. Vann Woodward, "History From Slave Sources," American Historical Review 79 (2) (1974): 470-481; Norman R. Yetman, "The Background of the Slave Narrative Collection," American Quarterly 19 (1967): 534-553; and Norman R. Yetman, "Ex-Slave Interviews and the Historiography of Slavery," American Quarterly 36 (1984): 181-210.

${ }^{19}$ Mercer, "Tapping the Slave Narrative Collection," 360; Escott, Slavery Remembered, 6-7, 13, 15; Blassingame, "Using the Testimony of Ex-Slaves", 181; Jacobs, "Twentieth-Century Slave Narratives," 224; Vann Woodward, "History from Slave Sources," 473.

${ }^{20}$ Yetman, "Ex-Slave Interviews", 182; Mercer, "Tapping the Slave Narrative Collection," 360; Jacobs, "Twentieth-Century Slave Narratives," 223, 225; Rawick, From Sundown to Sunup, xviii; Escott, Slavery Remembered, 16-17.

"I have based my research on all published volumes in this collection: Volumes 1 through 7 in Series number 1 , volumes 8 through 19 in Series 2, volumes 1 through 12 in what is known as Supplement, Series 1, and volumes 1 through 10 in Supplement, Series 2. References to either of the supplemental series will be distinguished by placing the notation S1or S2 in front of the citation, which will also include volume number, par number, and page numbers. Part numbers are necessary as many of the volumes have been sub-divided into separately paginated parts because interviews from more than one state have been published in the same volume. The part numbers will, for example, direct the reader to the correct page 373 in a volume that may contain two or three pages numbered 373 . Please note that due to the size of the collection, I have used the index to the collection to look for acts of resistance and have therefore had to accept the indexer's definition of "resistance." It is very possible then that there remain many more unfound incidences of resistance within the records in light of what may be differences of opinion as to what constitutes resistance. As more work is done with these records, hopefully these incidences will come to light as they are examined by historians whose concept of resistance is very different from that of the original indexer of the collection.

22 Jacqueline Jones, Labor of Love, 5, 12, 20; Obitko,"Custodians," 988; Escott, Slavery Remembered, 78.

"S1-8.3: 899-900.

${ }^{24}$ Ibid., 289.

255.3: 226.

2613.4: 254 .

${ }^{27}$ Ellison,"Resistance," 57; Frederick L. Olmsted, A Journey in the Seaboard Slave States (New York: Dix and Edwards, 1856), 190, 
quoted in White, $A r^{\prime} n^{\prime} t /$ a Woman, 80.

${ }^{28}$ Blassingame, "Using the Testimony of Ex-Slaves," 176-179; Mercer, "Tapping the Slave Narrative Collection," 360-361; Jacobs, "Twentieth-Century Slave Narratives," 224-225; Vann Woodward, "History from Slave Sources," 474; Escott, Slavery Remembered, 7 . 8.

${ }^{29}$ Escott, Slavery Remembered, 71-74, 90; Wood, "Some Aspects," 621.

${ }^{30} 5.3: 210$.

"11.8:267.

${ }^{32}$ S1-8. 3:929;6.1:68; 6.2:53; 11.8:. 292; 16. 2:. 67; S2-8.7:3059.

${ }^{33}$ Fox-Genovese, "Strategies," 425-426.

344.1:266-267.

${ }^{33} S 1-8.3: 1083 ; S 1-8.3: 1221 ; S 1-12.1: 97 ; 4.1: 33 ; 8.2: 258 ; 9.3: 256$;

9.4:102;12. 2:26-27;16. 5:11-12;18.1:53;17.1:35.

${ }^{36}$ Escott, Slavery Remembered, 75-76.

${ }^{37}$ Jacqueline Jones, Labor of Love, 31.

383.4:52-53.

${ }^{39} \mathrm{~S} 1-5.1: 180$.

${ }^{40} \mathrm{~S} 2-8.7: 2940 ; 11.8: 180$.

$11.1: 88-90$.

${ }^{42} 6.2: 158 ; 18.1: 12-13 ; 16.3: 64 ; 6.1: 220$.

${ }^{43}$ Francis A. Kemble, Journal of a Residence on a Georgia Plantation in 1838-1839, ed. John A. Scott (New York: Knopf, 1961), 235.

"White, Ar'n'll a Woman?, 81-82.

"Fox-Genovese, "Strategies," 423

${ }^{46}$ White, Ar'n'tl a Woman?, 82-83.

"Thelma Jennings, "Us Colored Women Had to Go Through a Plenty': Sexual Exploitation of African-American Slave Women," Journal of Women's History 1 (3) (Winter 1990): 46; Hine, "Female Slave Resistance," 663.

${ }^{48}$ White, Ar'n't I a Woman?, 85.

"White, Ar'n't I a Woman?, 84-85; Herbert Gutman, The Black Family in Slavery and Freedom, 1750-1925 (New York: Pantheon Books, 1976), 80-81.

${ }^{30}$ White, Ar'n'tl a Woman?, 85.

"Hine, "Female Slave Resistance," 665.

"Eugene Genovese, Roll, Jordan, 497.

${ }^{33}$ Fox-Genovese, "Strategies," 424.

${ }^{s 4}$ Hine, "Female Slave Resistance," 662.

"S2 - 5. 3: 1453; S2 - 6. 5:2284;S2-6. 5:2299.

${ }^{36} \mathrm{~S} 1-11.1: 54$.

"S1-9.4: 1447.

"Escott, Slavery Remembered, 87.

992.2:65-66. 
so5. 3:62-63.

'Davis, "Reflections", 9; Davis, Women, 21.

${ }^{62}$ Obitko, "Custodians," 991-993.

${ }^{63}$ White, Ar'n't I a Woman?, 78-79; Betty Wood, "Some Aspects," 621-622.

${ }^{64}$ Fox-Genovese, "Strategies," 421-422.

os5.4: 145 .

$664.1: 26$.

${ }^{67} 6.1: 60$.

$10.5: 49-50$.

${ }^{\infty} 6.2: 62$.

$107.1: 13$.

"15.2:49-50.

215.2:333.

"White, Ar'n't l a Woman?, 70-71; Wood, "Some Aspects,"609-610.

"White, Ar'n't I a Woman?, 74; Fox-Genovese, "Strategies," 416, 421; Escott, Slavery Remembered, 84.

${ }^{75} 2.2: 9$.

766.2: 144 .

$77.2: 13$

785.3:243.

"S1-5.1:7; S1-10.5:2189.

${ }^{80}$ White, Arn't l a Woman?, 72.

817.2: 13 .

827.2:13; S1- 10.5:2189.

${ }^{83} \mathrm{~S} 1-9.4: 1652 ; 8.2: 331 ; 11.8: 256 ; 11.8: 343 ; 16.6: .1 ; 5.3: 243 ; 16.4:$

$75 ;$ S2 - 6. 5: 2314; 10.6:257; S2-8.7:3228.

* $7.1: 317$.

ss $2.2: 10-11$.

${ }^{86}$ Hamilton, Up Before Daylight, 220-221.

${ }^{87}$ Raymond A. Bauer and Alice H. Bauer, "Day to Day Resistance to Slavery," Journal of Negro History 2 (1942): 389-390, 395.

${ }^{88}$ Although not cited in support of the forgoing analysis, further information may be found in the following: Carl Degler, Neither Black Nor White: Slavery and Race in Brazil and the United States (New York: Macmillan, 1971); Merton L. Dillon, Slavery Altacked: Southern Slaves and Their Allies, 1619-1865 (Baton Rouge: Louisiana State University Press, 1990); W.E.B. Du Bois, The Negro (London: Oxford University Press, 1970); Robert Fogel and Stanley L Engerman, Time on the Cross: The Economics of American Negro Slavery (New York: W.W. Norton, 1974); Martia Graham Goodson, "Medical-Botanical Contributions of African Slave Women to American Medicine," in Black Women in Uniled States History v.2, 473-483 (originally published in The Western Journal of Black Studies 11 [4] [1987]: 198-203); Martia Graham 
Goodson, "The Slave Narrative Collection: A Tool for Reconstructing Afro-American Women's History," in Black Women in United States History v. 2, 485-497 (originally published in The Western Journal of Black Studies 3 [Summer 1979]: 116122); Herbert Gutman, The Black Family in Slavery and Freedom (New York: Pantheon Books, 1976); Noreece T. Jones, Born a Child of Freedom, Yet a Slave: Mechanisms of Control and Strategies of Resistance in Antebellum South Carolina (Middletown, CN: Hanover Press of New England, 1990); Maude White Katz, "She Who Would Be Free: Resistance," in Black Women in United States History, v. 9, 319-329 (originally published in Freedomways [Winter 1962]); Kenneth M Stammp, The Peculiar Institution: Slavery in the Ante-Bellum South (New York: Vintage Books, 1956); Kenneth M Stampp, "The Historian and Southern Negro Slavery," American Historical Review (April 1952): 613-624; William Starobin, Industrial Slavery in the Old South (New York: Oxford University Press, 1970); Carter G. Woodson, The Education of the Negro Prior to 1861 (New York and London, 1915). 